\title{
Predation Efficiency of Insect Predators in Suppressing Red Mite, Tetranychus bioculatus Attacking Marigold
}

\author{
M.A. TALEB ${ }^{1 *}$ AND M.A. SARDAR ${ }^{2}$ \\ ${ }^{1}$ School of Agriculture and Rural Development, Bangladesh Open University, Gazipur, Bangladesh \\ ${ }^{2}$ Department of Entomology, Bangladesh Agricultural University, Mymensingh, Bangladesh
}

\begin{abstract}
Experiments were conducted to find out the efficiency of predators, Stethorus punctillum and Micraspis discolor in searching (behaviour), handling (time) and predating (efficiency) red mite, Tetranychus bioculatus (Wood-Mason) attacking marigold plants. Predators grub and adults spent their time through walking, running and flying for searching prey. The walking was common in both the stages and it was more common in S. punctillum than M. discolor. The grub and adult of S. punctillum were more active than that of $M$. discolor for searching prey. The handling times were measured by adding time required for recognition, capture and consumption of the prey. The predators recognized prey in 2.2-3.0 minutes after release. The capture and consumption time differed significantly. The study showed significantly different preying activity of predators on egg, larva, nymph and adult of red mite. The predating efficiency of S. punctillum and M. discolor was significantly higher when feeding on eggs and was ranged from 35.4 to 48.4 eggs per day than that of larva, nymph and adult of the mite. The rate of consumption of red mite by $S$. punctillum and $M$. discolor increased with increasing density of mite up to 30 mites and was correlated with its population density.
\end{abstract}

Key words: Searching behaviour, handling time, predation efficiency, Stethorus punctillum, Micraspis discolor, red mite, marigold.

\section{INTRODUCTION}

The use of pesticides is the usual practice for red mite control on different crops. The marigold growers also apply various pesticides to control red mite. Pesticidal control of mite is not only expensive, but also harmful to environment and hazardous to animals (Luckman and Metcalf 1978; Hussain 1984). The pesticide application alters the pest and predator or parasitoid ratios in the agroecosystem inflicting more harm than good.

The flower growers in developed countries use less pesticide or avoid application of pesticides. In recent years, mite control has been revolutionised by the application of predators in those countries. Ravensberg (1987), Deng et al. (1990), Zhang et al. (2001) and Gorski \& Eajfer (2003) generated some information on biological control of red mite by utilizing different predators in various horticultural plants and field crops.

* Corresponding author: Associate Professor, SARD, BOU; Tel: 88-02-9291101-4/327

(C) 2006 School of Agriculture and Rural Development, Bangladesh Open University, All rights reserved. 
The population growth of many mite pest species is efficiently controlled by their natural enemies (Nucifora and Vacante 1985). Many predators like Typhlodromus pyri reduce the population growth of red mites in natural condition (Kneifl and Knourkova 1991). The different species of insect predators have also significant impact on the population suppression of mites. The interacting components between natural enemies and prey should clearly be understood to enhance or augment the effect of natural enemies in a prey population (Rabb 1974). The interacting components include functional response occurring at individual level of both predator and prey and numerical response occurring at population level of both predator and prey (Holling 1959).

Several species of coccinellid beetles are known to be predaceous on different species of mites, most common predaceous species being Stethorus punctillum. They have been successfully employed in the biological control of many injurious mites (Shojai et al. 1996). S. punctillum has already established itself as one of the major mite predators and might be promising for biological control. This predator is widely distributed in European countries as a most common mite pest feeding species. The other coccinellied beetle, Micraspis discolor is predaceous on various important insect pests (Mani 1995). These predatory beetles can be used as viable agents for the biological control of the mites. Until recently, biological control was considered harmless and many available and promising species were tried. Control of red mites attacking marigold plants with the insect predators has not been reported yet in Bangladesh. The present research work was undertaken with a view to evaluate the biotic potential of insect predators, S. punctillum and $M$. discolor in suppressing red mite, $T$. bioculatus attacking marigold plants.

\section{MATERIALS AND METHODS}

The study utilizing Stethorus punctillum and Micraspis discolor for suppressing red mite was conducted in the laboratory of Department of Entomology of Bangladesh Agricultural University (BAU), Mymensingh between November, 2005 and March 2006. To ensure supply of the predators for the study the grubs of $S$. punctillum and $M$. discolor were cultured in the laboratory.

Adult adult beetles of the predators were collected from the marigold plant infested with red mite, Tetranychus bioculatus from the marigold garden of Bangladesh Agricultural University (BAU). Red mites were provided as food for mass culturing of the predators. The beetles were kept as single pair (male and female) in ten Petri dishes $(9.0 \mathrm{~cm} \times 1.5 \mathrm{~cm})$ for mating. Everyday field collected mites with infested marigold leaves were supplied in the Petri dishes as food for the predators. The observations were made at two times daily to examine oviposition of the beetles. Female predators laid yellow spindle shaped eggs in masses on the supplied leaves and surrounding wall of the Petri dishes. The eggs were kept undisturbed in the Petri dishes for hatching. After hatching eggs, newly emerged larvae were transferred to ten Petri dishes $(14.0 \mathrm{~cm}$ $x 1.5 \mathrm{~cm}$ ) with the help of a camel hair brush (00) and reared on red mites until adult emergence. Each Petri dish contained 10-15 grubs each of S. punctillum and M. discolor. Mites were supplied as food for the grub of the predators as described earlier.. The Petri dishes were kept undisturbed during the pupation of the grub of predators. The newly emerged beetles were placed in other Petri dishes of the same size allowing one male and one female for successful mating and laying eggs. Red mites were supplied to the new adults everyday in the same manner as indicated. The procedure was continued to ensure required number of adult predators for subsequent studies.

\section{Searching Behaviour of Predator Grub and Adult}

Forty prey (adult red mite) were placed in Petri dish on the marigold leaves and allowed to settle and fed in each replicate of the experiment. Mites quickly moved from the base to the apex of the leaves where they started feeding. Forty adults of red mites released in the centre, along the edge, apex, between apex and centre and at base of marigold leaf in Petri dish and a single predator grub or adult of $S$. punctillum and $M$. discolor was released in different leaf positions in the Petri dishes and allowed to search prey feeding on various portion of the leaves. Searching by predators was observed in respect of searching path and the handling time (recognition time, capture time and consumption time) for the predator and recorded. The procedure for recording prey and predator behaviour was followed as described by Wratten (1973). 


\section{Consumption of Immature Stages of Red Mite by Predators}

Fifty eggs, larvae and nymphs of the mite were placed separately per replicate (five replicates) on marigold leaves in the Petri dishes $(9.0 \mathrm{~cm} \times 1.5 \mathrm{~cm})$ and a single predator of the required stage was then allowed to feed immature stages of mite. The number of mites increased or decreased was then observed in each replicate at 24 hours of predator release.

\section{Functional Response of Predators}

To study the functional response of predators, S. punctillum and M. discolor, the experiments was conducted on marigold plants raised in earthen pot. The study was based on different population densities of red mite as prey attacked by fixed/single number of grub and adult of predators. The method followed was that of Tamaki and Long (1978). Five grubs of predators one in single marigold plant caged with 10, 20, 30, 40 and 50 number of mite. Each treatment was replicated five times and one marigold plant considered as a replicate. The same procedure was followed for the adult predators. Caging was made for covering the whole plant by nylon net. The cages with mite were kept free from other predator before treatment. The observations were made on the number of mites increased or decreased in each treatment at 24, 48 and 72 hours of predator release. Small quantity of vaseline was applied around the base of the marigold plants which received predator grub to avoid its escape from the caged plant. The experiment was laid out following Completely Randomized Design (CRD). The number of mites were counted in leaves, stems and twigs of the plant at 24,48 and 72 hours of predator release. During the study room temperature was recorded in the laboratory by using dry and wet thermometer. Data obtained from the study were analyzed using computer software for one factor analysis following CRD and means were separated by Duncan's Multiple Range Test (DMRT).

\section{RESULTS}

Searching Behaviour of Predators for Prey: The predators, Stethorus punctillum and Micraspis discolor exhibited different types of movement for searching red mites. Typical search patterns of the grub of these predators were the walking and running towards the prey. The exactly $60 \% \mathrm{~S}$. punctillum grub ran straight and sometimes in circle for the prey (Table 1). The same proportion of grub of $M$. discolor walked in haphazard manner and sometimes quickly walked towards the prey. The remaining $40 \%$ grub of the predators searched prey by walking zigzag way. Sometime quick walking was evident among the S. punctillum and straight running in M. discolor (Table 1).

Table 1. Different types of behaviour shown by grub and adult of predators, Stethorus punctillum and Micraspis discolor for searching red mite

\begin{tabular}{ccccc}
\hline $\begin{array}{c}\text { Movement } \\
\text { types }\end{array}$ & \multicolumn{2}{c}{ Larva } & Adult \\
\cline { 2 - 5 } 1. Walking & S. punctillum & M. discolor & S. punctillum & M. discolor \\
\hline \hline & $\begin{array}{c}\text { Walking not straight } \\
\text { (zigzag) and } \\
\text { sometimes walking } \\
\text { quickly (40\%) }\end{array}$ & $\begin{array}{c}\text { Walking not } \\
\text { straight and } \\
\text { sometimes walking } \\
\text { quickly (60\%) }\end{array}$ & $\begin{array}{c}\text { Walking not straight } \\
(40 \%)\end{array}$ & $\begin{array}{c}\text { Walking not straight } \\
\text { and sometimes } \\
\text { walking straight } \\
(60 \%)\end{array}$ \\
2. Running & $\begin{array}{c}\text { Running straight and } \\
\text { sometimes running in } \\
\text { circle (60\%) }\end{array}$ & $\begin{array}{c}\text { Running straight } \\
(40 \%)\end{array}$ & $\begin{array}{c}\text { Running straight and } \\
\text { sometimes running } \\
\text { zigzag (30\%) }\end{array}$ & $\begin{array}{c}\text { Running straight and } \\
\text { sometimes running in } \\
\text { circle (20\%) }\end{array}$ \\
3. Flying & - & & $\begin{array}{c}\text { Flying straight and } \\
\text { sometimes flying in } \\
\text { haphazard (30\%) }\end{array}$ & $\begin{array}{c}\text { Flying straight and } \\
\text { sometimes flying in } \\
\text { circle (20\%) }\end{array}$ \\
\hline
\end{tabular}

Figures in parentheses represent percentage of grubs/adults showing walking, running and flying behaviour

The adult beetles of S. punctillum and $M$. discolor moved towards mites by walking, running and flying. About $40 \%$ S. punctillum beetle moved by walking but not in straight way, but they ran straight and also flew straight with slightly in haphazard manner. The adults of $M$. discolor walked 
straight to the prey and running and flying in circle was common, but running straight and flying were evident in searching the prey (Table 1).

Handling Time of Predators for Prey: The handling times of the predators were measured by adding time required for recognition, capture and consumption of the prey. These two species of predators recognized prey in 2.2-3.0 minutes after release (Table 2). The capture and consumption time differed significantly $(P<0.01-0.05)$. The capture time of prey was the highest in the grub of $S$. punctillum followed by the adult of this predator. The lowest capture time was recorded for adults of $M$. discolor but similar to its grub. The highest consumption time was required by S. punctillium grub but found similar to their adults and this was followed by $M$. discolor grub. The adult of $M$. discolor required the lowest time for the consumption of prey.

Table 2. Handling time of predator at grub and adult stages preying on red mite.

\begin{tabular}{lcccc}
\hline \multirow{2}{*}{ Stages of Predators } & Prey density & \multicolumn{3}{c}{ Mean handling time (minute) } \\
\cline { 3 - 5 } & & $\begin{array}{c}\text { Recognition } \\
\text { time }\end{array}$ & Capture time & $\begin{array}{c}\text { Consumption } \\
\text { time }\end{array}$ \\
\hline \hline S. punctillum grub & 40 & 3.05 & $2.13 \mathrm{a}$ & $1.89 \mathrm{a}$ \\
M. discolor grub & 40 & 2.48 & $1.53 \mathrm{~b}$ & $1.64 \mathrm{ab}$ \\
S. punctillum adult & 40 & 2.66 & $1.80 \mathrm{ab}$ & $1.74 \mathrm{a}$ \\
M. discolor adult & 40 & 2.20 & $1.30 \mathrm{~b}$ & $1.41 \mathrm{~b}$ \\
\hline
\end{tabular}

Means having same letter in a column did not differ significantly $(P<0.01-0.05)$

Predators on Prey Consumption: The grub and adult of predators, S. punctillum and M. discolor were allowed to feed egg, larva and nymph of mite (Table 3). The grub of S. punctillum consumed the highest number (48.40) of eggs of mite in a day which was identical to that of adults of the predator. The egg consumption was lower in both grub and adult of $M$. discolor than that of $S$. punctillium. The consumption rate of grub was similar to adult $M$. discolor. The rate of consumption of larvae and nymph of prey by these predators was lower compared to egg consumption. The significantly the highest numbers of mite larva and nymph were eaten by S. punctillium grub. $M$. discolor grub and S. punctillum adult consumed similar number of mite larva at the rate of 26.4027.80 per day. Nymph consumption was the lowest in $M$. discolor adult but identical to its grub.

Table 3. Consumption of different stages of red mite by grub and adult of predators, Stethorus punctillum and Micraspis discolor per day

\begin{tabular}{lcccc}
\hline Stages of Predators & Prey density & \multicolumn{3}{c}{ Mean red mite (no.) consumed at different stages } \\
\cline { 3 - 5 } & & Egg & Larva & Nymph \\
\hline \hline S. punctillum grub & 50 & $48.40 \mathrm{a}$ & $34.20 \mathrm{a}$ & $26.00 \mathrm{a}$ \\
M. discolor grub & 50 & $38.70 \mathrm{~b}$ & $26.40 \mathrm{~b}$ & $19.60 \mathrm{c}$ \\
S. punctillum adult & 50 & $47.00 \mathrm{a}$ & $27.80 \mathrm{~b}$ & $22.20 \mathrm{~b}$ \\
M. discolor adult & 50 & $35.40 \mathrm{~b}$ & $22.60 \mathrm{c}$ & $17.60 \mathrm{c}$ \\
\hline
\end{tabular}

Means having same letter in a column did not differ significantly $(P<0.01)$

The adult red mite consumption at five densities by the grub and adult of predators, $S$. punctillum and $M$. discolor at 24, 48 and 72 hours after release are presented in Table 4 . The predators fed significantly $(P<0.01)$ higher at increasing prey density. S. punctillum grub consumed 9.8 adult red mites in 24 hours while it was 9.6 in case of $M$. discolor grub. The grub of both the predators commenced all the adult prey within 48 hours upto a density of 30 prey. At 40 and 50 densities of prey, the consumption rate increased and there were some prey eaten in 72 hours. The consumption rate of adult red mite by the predator adults was slightly lower compared to grub in different prey densities at different hours of release. The adults S. punctillum and M. discolor fed some adult mite prey in 72 hours at densities of 30, 40 and 50 (Table 4). The consumption of adult red mites increased at all prey densities at 48 and 72 hours of release and reached $100 \%$ by both predator grub and adult. There were significant correlations between the adult mite prey consumption and prey density by the grub and adults of S. punctillum and M. discolor at 24 and 48 hours of release on marigold plant (Fig. 1). 
Table 4. Consumption of adult red mite by the grub and adults of Stethorus punctillum and Micraspis. discolor (in parentheses) at different hours of release (HR) at different prey densities

\begin{tabular}{ccccccc}
\hline \multirow{2}{*}{$\begin{array}{c}\text { Prey } \\
\text { density }\end{array}$} & \multicolumn{3}{c}{ Cumulative mean prey (no.) consume at different hours of release (HR) } \\
\cline { 2 - 7 } & \multicolumn{3}{c}{ Predator grub } & \multicolumn{3}{c}{ Predator adult } \\
\cline { 2 - 7 } & $\mathbf{2 4 ~ H R}$ & 48 HR & 72 HR & 24 HR & 48 HR & 72 HR \\
\hline \hline \multirow{2}{*}{10} & $9.8 \mathrm{~d}$ & 10.0 & & $9.8 \mathrm{e}$ & 10.0 & \\
& $(9.6 \mathrm{D})$ & $(10.0)$ & & $(7.8 \mathrm{E})$ & $(10.0)$ & \\
20 & $15.8 \mathrm{c}$ & 20.0 & & $13.0 \mathrm{~d}$ & 20.0 & \\
& $(11.8 \mathrm{C})$ & $(20.0)$ & & $(11.2 \mathrm{D})$ & $(20.0)$ & \\
30 & $18.6 \mathrm{~b}$ & 30.0 & - & $15.0 \mathrm{c}$ & 29.4 & 30.0 \\
& $(15.0 \mathrm{~B})$ & $(29.4)$ & $(30.0)$ & $(13.2 \mathrm{C})$ & $(25.8)$ & $(30.0)$ \\
40 & $23.2 \mathrm{a}$ & 39.4 & 40.0 & $17.8 \mathrm{~b}$ & 35.4 & 40.0 \\
& $(18.6 \mathrm{~A})$ & $(37.4)$ & $(40.0)$ & $(15.6 \mathrm{~B})$ & $(30.8)$ & $(40.0)$ \\
50 & $24.2 \mathrm{a}$ & 48.6 & 50.0 & $21.2 \mathrm{a}$ & 42.6 & 50.0 \\
& $(18.8 \mathrm{~A})$ & $(37.8)$ & $(50.0)$ & $(17.4 \mathrm{~A})$ & $(34.2)$ & $(50.0)$ \\
\hline
\end{tabular}

Means having same letter in a column did not differ significantly $(P<0.01)$ and these were analyzed separately for two predators
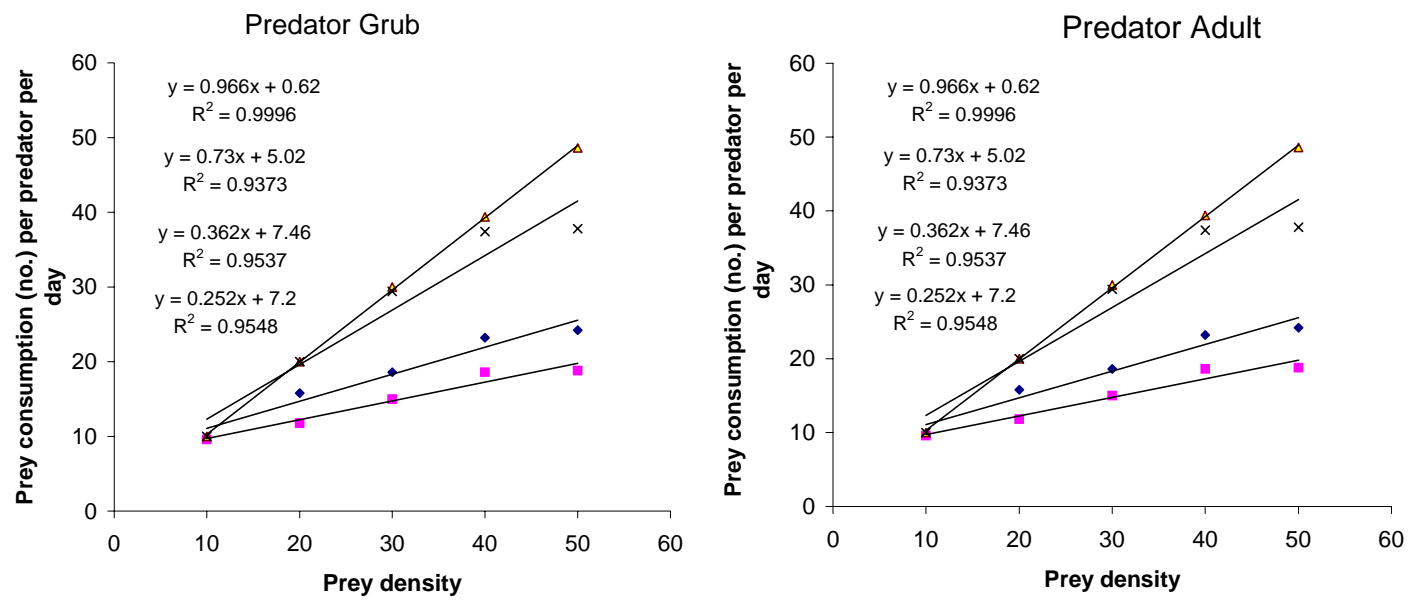

Fig.1. Relationship between prey density (adult red mite) and prey consumption by the grub and adults of S. punctillum and M. discolor in $\mathbf{2 4}$ and $\mathbf{4 8}$ hours on marigold plant

\section{DISCUSSION}

Searching activities through walking, running and flying was commonly observed in case of both the adult species of beetle. Walking and running were also commonly seen among the grubs of both the species. Evans (1976) also found similar behaviour. He observed that the coccinellid beetle's searching was consisting of spending all their available time for searching prey and the patterns of search was influenced by the topography of the plant, particularly the mid-rib, veins and leaf edges as favoured search areas for the hungry $S$. punctillum. He also indicated that $S$. punctillum and $M$. discolor moved rapidly for searching prey where the probability of encountering prey was high. The searching efficiency of predator, Anblyseius cucumeris was low at less than 5 prey mites per leaf and most of them did not lay any eggs (Zhang et al. 2001). They also opined that many factors affect searching of coccinellids and the rate of change of direction following a successful feeding leads to more time being spent in regions of high prey density. 
Handling time was significantly more in S. punctillum than M. discolor. It might be influenced due to the smaller body size of $S$. punctillum suitable for capturing red mite which was also small. In the functional response, S. punctillum larva consumed a maximum of 48.40 mite eggs, 34.20 mite larvae, 26.00 mite nymphs and 24.20 adult mites in a day whereas these were lower in case of M. discolor at larval stage. The consumption rate of egg, larva, nymph and adult of mite by the adult of both predators was less than that of grub of these predators. Collyer (1993) reported that S. punctillum adult consumed 20 mites daily whereas the grub consumed 24 spider mites, Metatetranychus ulmi per day. Moreton (1978) studied that S. punctillum adult required 20-40 spider mites per day for subsistence and might consume as many as 140 per day and the larva might consume 250 mites a day. On the other hand Gorski and Eajfer (2003) reported that each S. punctillum individual destroys about 10 adult mites and 50 mite eggs per day. This finding supported the observation of the present study.

The rate of feeding increased significantly up to 30 adult mites and prey density was correlated with rate of consumption. The mite densities 40 and 50 did not show any significant difference for consumption. It indicated that these two densities of prey might satisfy the requirements of food for the predators up to 48 hours in predator prey association.

The predation of S. punctillum and $M$. discolor increased at the high density of prey. Although same number of predator grub and adult used at different prey densities in caged marigold plants, the degree of response by predators varied. The recent work was carried out by Zhang et al. (2001) in the laboratory on the effects of various periods of predation on the functional response of Amblyseius cucumeris and at different densities of citrus red mite, Panonychus citri. They found that the rate of prey consumption was found to increase significantly with the increase in the predation period and prey density. The above work was more or less in consistent with the results of the present study. From the present study it may be revealed that the biotic potential of both the species of predator in suppressing red mite attacking marigold is encouraging and need further thorough investigation.

\section{LITERATURE CITED}

Collyer, E. 1993. Biology of some predatory insects and mites associated with the fruit tree red spider mite, Metatetranychus ulmi (Koch) in south-eastern England. J. Hort. Sci. 28, 85-97.

Deng, G. R., Yang, H. H. and Jin, M. X. 1990. Experiment on integrated control of citrus red mite. J. Guangxi Agril. College. 9(4), 10-18.

Evans, H. F. 1976. The searching behaviour of Anthocoris confusus (Reuter) in relation to prey density and plant surface topography. Ecol. Entomol. 1, 163-169.

Gorski, R. and Eajfer, B. 2003. Control of red spider mite on indoor crops using the lady bird Stethorus punctillum. Ochron Roslin. 47(1), 10-11.

Holling, C. S. 1959. The components of predation as revealed by a study of small mammal predation of the European pine sawfly. Canad. Ent. 92, 293-320.

Hussain, M. 1984. Controlling rice borers under Bangladesh conditions. Pestology. 8(8), 28-36.

Kneifl, V. and Knourkova, J. 1991. Using the predatory mite, Typhlodromus pyri Scheuten in integrated apple pest management. Sbornik UVTIZ, Zahradnictvi. 18(2), 145-149.

Luckmann, W. H. and Metcaff, R. L. 1978. The pest management concept. An introduction to insect pest management. John. Willey and sons. New York. 3-35.

Mani, M. 1995. Studies of natural enemies of wax scale, Drepanococcus chiton (Green) on ber and guava. Entom. 20(2), 55-58.

Moreton, B. D. 1978. Beneficial insects and mites. Ministry of Agriculture, Fisheries and Food (Her Majesty's Stationery Office). U.K. 118 p.

Nucifora, A. and Vacante, V. 1985. Present possibilities of control of red spider mite in protected horticultural and floricultural crops. Tecnica Agricola. 37(3-4), 323-345.

Rabb, R. L. 1974. Naturally occurring biological control in the eastern United States, with particular reference to tobacco insects. In: Huffaker, C.B. (ed.). Biological control. Plenum Publ. Co. New York: 294-309. 
Ravensberg, W. J. 1987. Mass production of beneficial arthropods: commercialization and other problems. In: Possibilities and Limitations of Biological Plant Protection, German Federal Republic.. 344, 259-268.

Shojai, M., Ostovan, H., Khodaman, M. Hoseini and Daniali, M. 1996. The occurrence of Orius minutes (L.) in apple orchards Mashhad. Biology and Laboratory rearing for biocontrol of European red mite. J. Agril. Sci. 2(5-6), 5-20.

Tamaki, G. and Long, G. E. 1978. Predator complex on the green peach aphid on sugar beet; expansion to the predator power and efficiency model. Environ. Entomol. 7(6), 835-842.

Wratten, S. D. 1973. The effectiveness of the coccinellid beetle, Adalia bipunctata (L.) as a predator of the lime aphid, Eucallipterus tiliae L. J. Anim. Ecol. 42, 785-802.

Zhang, Y. X., Zhang, Z. Q., Chen, C. P., Lin, J. Z. and Chen, X. 2001. Amblyseius cucumeris (Acari: Phytoseiidae) as a biocontrol agent against Panonychus citri (Acari:Tetranychidae) on citrus in China. Systematic and Applied Acarology. 6, 35-44. 